https://doi.org/10.4314/ijs.v22i1.8

Ife Journal of Science vol. 22, no. 1 (2020)

\title{
COMPARATIVE ANATOMICAL STUDIES OF TWO SPECIES OF TALINUM OCCURRING IN SOUTHWESTERN, NIGERIA
}

\author{
${ }^{1 *}$ Adenegan-Alakinde T. A. and ${ }^{2}$ Ojo F. M. \\ ${ }^{1}$ Department of Biology, Adeyemi College of Education, Ondo, Ondo State, Nigeria. ${ }^{2}$ Department of Biological \\ Sciences (Botany Programme), Ondo State University of Science and Technology, Okitipupa. Ondo State, Nigeria, \\ email: olufunmilola_07@yahoo.co.uk, Tel: +2348069184017. \\ *Corresponding author's e-mail: taiwoadeneganalakinde@gmail.com, Tel: 234-8066712798.
}

(Received: $19^{\text {th }}$ May, 2019; Accepted: 28 ${ }^{\text {th }}$ December, 2019)

\section{ABSTRACT}

Leaf anatomical studies were carried out on two species of Talinum: Talinum triangulare (Jacq.) Willd and Talinum paniculatum (Jacq.) Gaertn to fill the knowledge gap in the understanding of the taxonomic relationship between the two species of the genus Talinum studied. Widens of T. paniculatum were collected and established in nursery bags in Ondo city, Ondo State, Nigeria. At flowering, the leaves were collected for anatomical studies. Free hand peeling was done for leaf portions that were used for epidermal studies. Leaves were cleared for venation using standard methods. Transverse sections of the leaf blade, mid rib and petiole were cut from the median portion of the materials available using Reicheirt sliding microtome at $8-15 \mu \mathrm{m}$. Sections were stained in Safranin $\mathrm{O}$ and counter stained in Alcian blue. These were rinsed in several water changes to remove excess stain and then treated to serial grades of alcohol. The stained sections were mounted in dilute glycerol for anatomical studies. Observations were made with compound light microscope. Photomicrographs were taken with 3013 ACCU-SCOPE trinocular microscope with digital camera. The study revealed that the leaves are amphistomatic, stomata is more abundant on the abaxial surface, paracytic stomata accompanied by other stomata types. Sclereids and druses were observed on the two species. The two species can be distinguished based on the anticlinal walls on the adaxial surface which is straight to slightly undulating.

Key words: Amphistomatic, Anticlinal walls, Paracytic, Undulating

\section{INTRODUCTION}

The genus Talinum Adans consists of 50 species of semi succulent herbs or subshrubs distributed in the tropics and sub tropics of America, Africa and Asia (McNeil, 1974). According to Veselova et al., (2012) members were initially part of Portulacaceae but later segregated to the family Talinaceae. Hutchinson and Dalziel (1954) reported that only two species are identified in the West Coast of Africa. Talinum triangulare (Jacq.) Willd also known as T. fruticosum (L.) Juss. and $T$. portulacifolium (Rahl.).

Nyananyo and Olowokudejo (1986) reported that in Nigeria the genus is represented by two species: Talinum triangulare and Talinum cuneifolium (Willd.DC (syn, T. portulacifolium (Forssk). According to Oziegbe et al., (2012) the genus Talinum is well represented in Nigeria but the most commonly eaten is $T$. triangulare represented by variants with white and pink petals. Nya and Eka (2015) however noted that Nigeria has a rich germplasm of Talinum. They identified five species namely: T. triangulare (Jacq.) Willd, T. fruticosum (L) Juss., T. paniculatum (Jacq.) Gaertn., T. crassifolium (Jacq.) Willd and T. cuneifolium.

Nyananyo and Olowokudejo (1986) observed that the floristic treatment of Hutchinson and Dalziel (1954) showed that $T$. triangulare and $T$. cuneifolium are very similar, almost indistinguishable morphologically but separated by leaf apex; leaf apex is emarginate or muronate in $T$. triangulare while it is aciculate in $T$ cuneifolium. Because these characters are not reliable, there is a need to search for more stable characters useful for delimiting the species.

T. triangulare (Jacq.) Willd. (Portulacaceae) is a caulescent, perennial herb growing to a height of $80-100 \mathrm{~cm}$. It is popularly known as waterleaf because of its high moisture content of almost $90.8 \mathrm{~g}$ per $100 \mathrm{~g}$ of edible leaf as described by Fontem and Schippers (2010). The plant is widely grown in most of the humid tropical continents 
such as West Africa, Asia and South America (Ezekwe, et al., 2002). It thrives well under shade and in cloudy weather. The plant has a rich content of crude protein, total lipids, essential oils, cardiac glycosides, flavonoids and polyphenols (Sridhar and Lakshminarayana, 1993). Preliminary phytochemical studies on $T$. triangulare revealed the presence of omega-3-fatty acids and high levels of essential nutrients like minerals (such as calcium, potassium and magnesium), soluble fibres (such as pectin), vitamin $C, \alpha$ and $\beta$ tocopherols and $\beta$-carotene which are required for growth and development (Ezekwe et al., 2002). The leaf extracts of waterleaf have been proved to possess remarkable antioxidant activity and high kaempferol content (Andarwulan, et al., 2010). Waterleaf is a mucilaginous vegetable with high oxalate content and is rich in saponins. Talinum triangulare leaves have been implicated medically in the management of cardiovascular diseases such as stroke and obesity (Mbang et al., 2008).

T. paniculatum is pantropical, found in several countries including Brazil, Ghana, Nigeria, Mexico and Sri Lanka (Reis et al., 2015). It is a perennial subshrub; reaching up to $30 \mathrm{~cm}$ in height. T. paniculatum is a wild deciduous perennial herb with well-developed root system; naturally grown around the world. $T$. paniculatum have traditional uses in Brazil; it is cultivated as ornamental in house, gardens and small farms. T. paniculatum is found as a regrowth of waste lands i.e. ruderals. They are rarely consumed as potherbs except during lean seasons because of its sharp taste (Ramos et al., 2010, Mosango, 2017). It is used to treat urine with bad smell, gastrointestinal disorders, oedemas, inflammatory skin diseases, skin lesions, scratches and scrapes, arthritis, scurvy, nerve distension (Sidney et al., 2010). Traditionally it is used in the treatment of type-2-diabetes (Thanamool et al. 2013). It is used to treat diarrhea, dysmenorrhea, spleen disorders, impotence, male infertility, wounds and ulcers. The leaves are antidiuretic, aphrodisiac, anti-nociceptive and edematogenic (Kumari et al.2017).

Information on the taxonomy of the genus
Talinum is scanty especially anatomical studies in Nigeria. However, few studies have highlighted the foliar micro morphology of the species of Portulacaceae (Kadiri, 2006); such include foliar epidermal studies in the genus Talinum in Nigeria (Nyananyo and Olowokudeju, 1986) and embryology of $T$. triangulare and $T$. paniculatum (Veselova et al., 2012). Molero et al., (2006) reported on the chromosome number of the genus as $2 n=24$. Swarna and Ravindhran (2013) reported on pharmacognostical and phytochemical evaluation of Talinum triangulare (Jacq.) Willd. All the information provided in these studies is not sufficient to give appropriate taxonomic evaluation of the members of the genus occurring in Nigeria. This study therefore seeks to document and evaluate the taxonomic relationship between $T$. triangulare and $T$. paniculatum occurring in south west, Nigeria using foliar anatomical characters.

\section{MATERIALS AND METHODS Plant Collections}

Two species of Talinum namely Talinum triangulare (Jacq.) Willd and Talinum paniculatum (Jacq.) Gaertn. were studied. Talinum triangulare was collected at Adeyemi College of Education, Ondo city, Ondo state, Nigeria with coordinates $7.0707^{\circ} \mathrm{N}, 4.8184^{\circ} \mathrm{E}$ while Talinum paniculatum was collected at Joseph Ayodele Babalola University, Ikeja Arakeji, Ilesa in Osun state, Nigeria with coordinates 7.30 $00^{\circ} \mathrm{N}, 4.4900^{\circ} \mathrm{E}$. At flowering, the leaves were collected for anatomical studies. Widens of $T$. paniculatum were collected and established in nursery bags in Ondo city, Ondo state, Nigeria and at flowering, the leaves were collected for anatomical studies.

\section{Leaf Epidermal Studies.}

Free hand peeling was done for leaf portions that were used for epidermal studies. Materials were rinsed in several changes of water to ensure that the epidermal peels are free of fragments and then stored in 50\% alcohol for anatomical studies. Peels for epidermal studies were stained in Safranin $O$ for 3 minutes, rinsed in water to remove excess stain. Stained sections were treated 
in serial grades of alcohol for proper dehydration. All stained epidermal peels were mounted in dilute glycerol for microscopic examination.

\section{Venation Patterns}

For comparative studies of the venation pattern of the leaves, sizeable portions were taken from standard median portion of mature leaves of the two species of Talinum. This was mid-way between the base and the apex of the leaf lamina and mid-way between the margin and the mid rib. Leaves were cut into sizeable portions so that the entire surface areas of the leaves were exposed to the action of the clearing agent. The different portions of the leaves were boiled in $90 \%$ alcohol for 15 minutes in order to remove the chlorophyll and washed in $3-4$ changes of water to remove the alcohol. The partly cleared leaves were cleared in $5 \%$ solution of domestic bleaching agent, parazone until cleared leaves were observed. The leaf portions were finally washed in several changes of water to get rid of the bleaching agent. The cleared leaves were stored in 50\% alcohol for anatomical studies. Leaves were stained in Safranin $O$ for 3 minutes and were rinsed in water to remove excess stain. Stained cleared leaves were treated in serial grades of alcohol. Differentiation in acid alcohol and dehydration was done. All stained materials were mounted in dilute glycerol for microscopic examination.

Transverse Section of the Leaf Blade, Mid rib and Petiole

Transverse sections of the leaf blade, mid rib and petiole were cut from the median portion of the materials available using Reicheirt sliding microtome at $8-15 \mu \mathrm{m}$. Sections were stained in Safranin $O$ for 3 minutes, rinsed in water to remove excess stain and counter stained in Alcian blue for 3 minutes. These were rinsed in water to remove excess stain and treated to serial grades of alcohol before mounting in dilute glycerol for anatomical studies.

Photomicrographs of all the sections were taken using 3013 ACCU-SCOPE trinocular microscope with digital camera.

\section{RESULTS \\ Talinum triangulare \\ Epidermal Cells}

Abaxial Surface (Plate $1 \mathrm{~A}$ and $\mathrm{B}$ )

The abaxial epidermal are polygonal with deeply undulating anticlinal walls. Stomata are randomly distributed, paracytic, occasionally laterocyclic stomata were found. Abnormal stomata are more frequent on the abaxial surface. The abnormal stomata that were observed are characterized by absence of guard cell, presence of one guard cell and closed stomata pore. Druses are present.

Adaxial Surface (Plate 1C and D)

Epidermal cells are polygonal with wavy to slightly undulating anticlinal walls. Paracytic stomata were randomly distributed in the epidermal surface. Osteosclereids and asterosclereids present. Druses were present. 

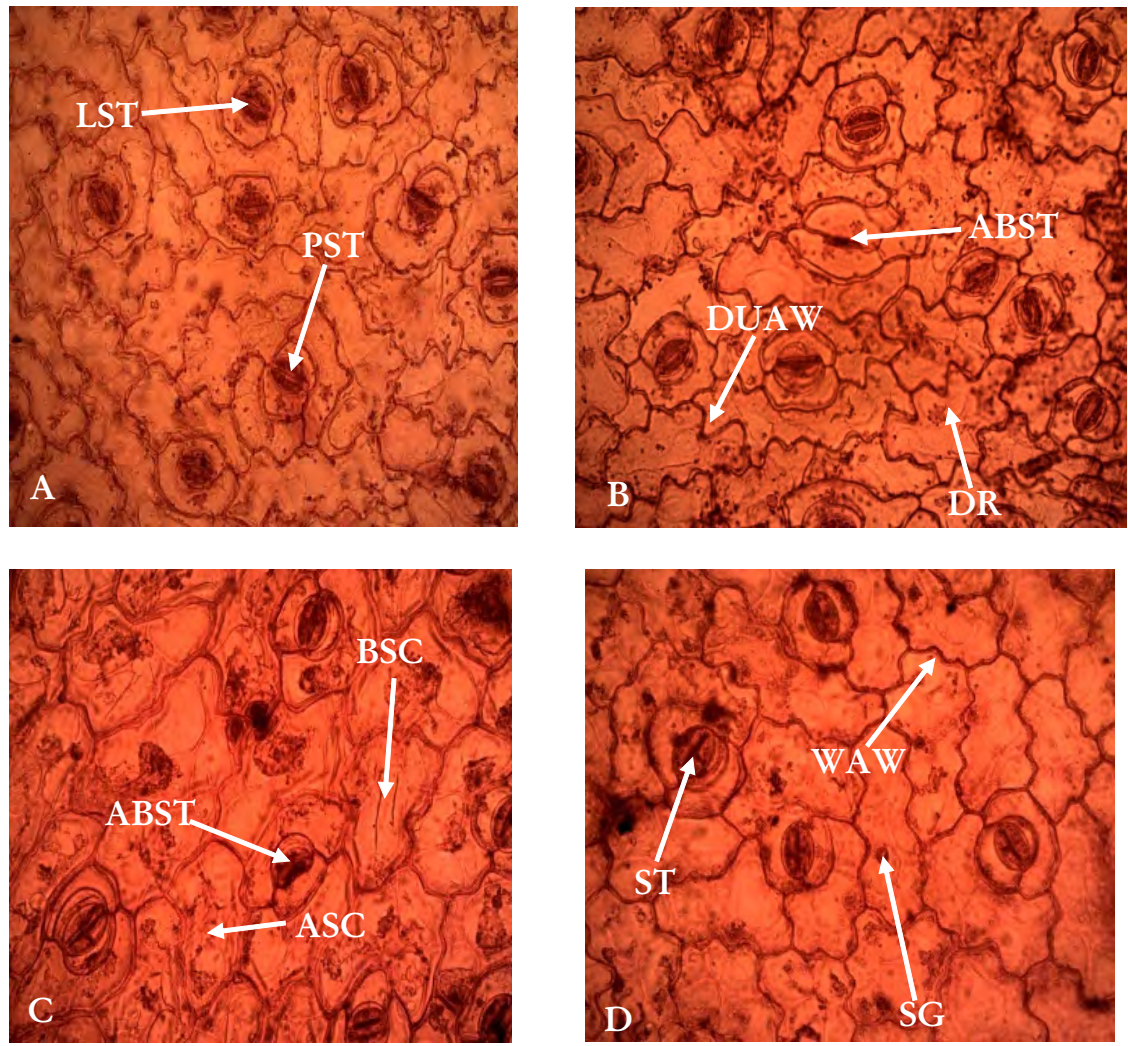

Plate 1: Abaxial and Adaxial Surfaces of Leaf Epidermal Studies of T. triangulare

A- showing laterocyclic stomata and paracytic stomata; B-abnormal stomata, druses and deeply undulating anticlinal walls; C- abnormal stomata, asterosceleids and osteosclereids; D-starch grains, stomata and wavy anticlinal wall

Abbreviations: ABST - Abnormal stomata; ASC - Asterosclereids; BSC - Bony shaped sclereids; DR - Druses; DUAW - Deeply undulating anticlinal walls; LST - Laterocytic stomata; PST - Paracytic stomata; SG - Starch grains; ST - Stomata. UAW - Undulating anticlinal wall

\section{Venation(Plate 2)}

Areole is polygonal of various sizes and shapes; Veins consist of tracheids, abundant starch grains that were scattered and lot of crystal druses. Veinlet ending could be linear or straight, curve, forked; nerve endings may be one or two.

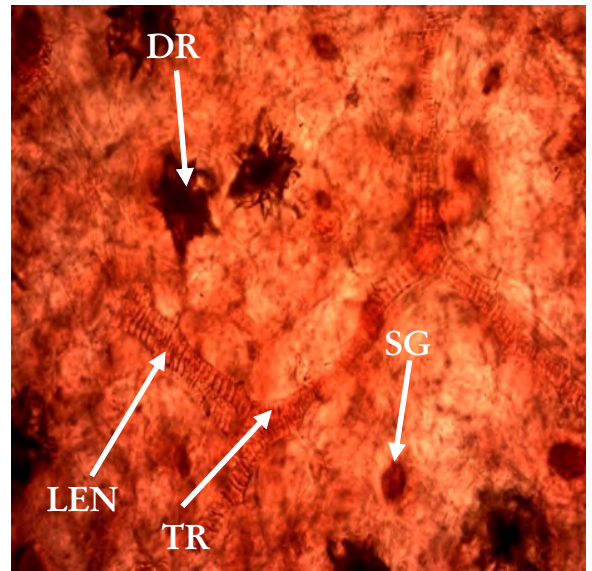

Plate 2: Venation Patterns of T. triangulare

Abbreviations: DR - Druses; LEN - Linear ending; SG - Starch grain; TR - Tracheids 
Transverse Section of Leaf Blade (Plate 3A and B)

The transverse section of the leaf blade showed biseriate and triseriate epidermis (upper and lower). Stomata occurred on the upper and lower epidermis. Epidermal portion were separated from the mesophyll by sclerenchyma tissues. The mesophyll were not differentiated, 2-3 layered. Cells of the mesophyll were polygonal, more or less circular. Bundle sheath cells line the lamina. Druses were present.

\section{Transverse Section of Leaf mid rib (Plate 3C)}

It is dorsiventrally shaped with slight depression on median portion of upper surface. The lower epidermis is biseriate, circular to cylindrical arranged perpendicular to the cuticle. The upper epidermis is biseriate to triseriate with more or less circular cells. Vascular bundle is collateral closed. Bundle sheath lies on the arms of midrib. Sclerenchyma tissue lines the upper epidermis. Druses are present.

\section{Transverse Section of Petiole (Plate 3D)}

More or circular with slight depression on the median part of the adaxial surface. The cuticle is thin. The abaxial surface is uniseriate to biseriate while the adaxial epidermis is uniseriate to multiseriate, with cylindrical, circular and polygonal cells. The ground tissue is collenchyma, vascular bundle is amphicribral. Druses are present.
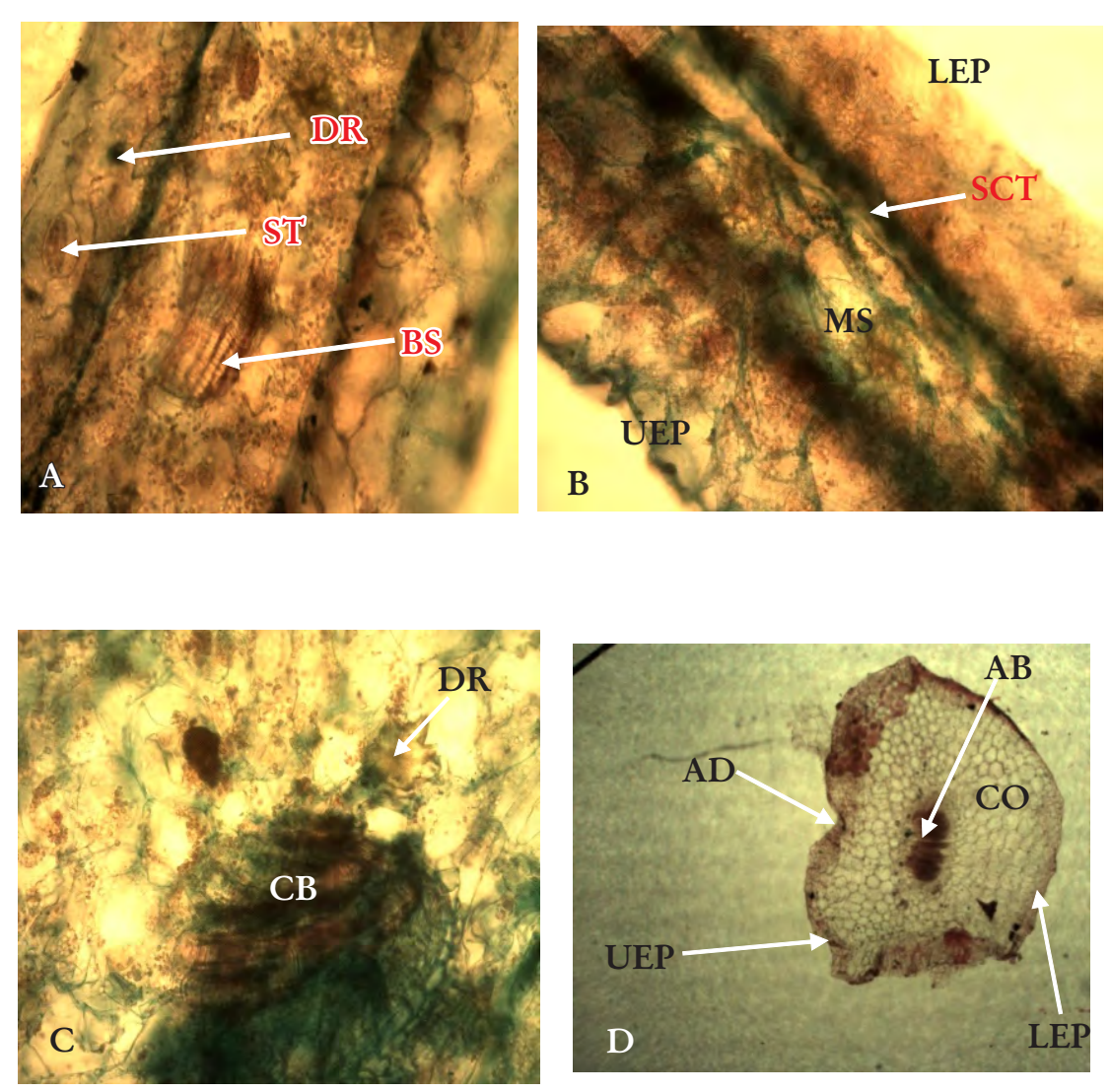

Plate 3: Transverse Sections of Leaf Lamina, Midrib and Petiole of T. triangulare

A- showing bundle sheath, druses and stomata; B-lower epidermis, mesophyll, sclerenchyma tissue and upper epidermis;C- collateral bundles and druses; D- amphicribral bundle, adaxial depression, collenchyma, lower epidermis and upper epidermis

Abbreviations: AB Amphicribral bundle, AD Adaxial depression, BS - Bundle sheath, $\mathrm{CB}$ - Collateral bundle, CO - Collenchyma, DR Druses, LEP - Lower epidermis, MS - Mesophyll, SCT - Sclerenchyma tissues, ST - Stomata, UEP - Upper epidermis.

\section{T.paniculatum}

Epidermal Cells

Abaxial Surface (Plate $4 \mathrm{~A}$ and B)

Epidermal cells were polygonal with wavy to undulating anticlinal walls. Stomata were randomly distributed as paracytic and elliptic. Columnar sclereids and asterosclereid were present. Starch grains were found inside the epidermal cells and walls. Druses present.
Adaxial Surface (Plate 4 C, D and E)

In the non-venous areas, the epidermal cells were polygonal with wavy to undulating anticlinal walls. Epidermal cells in the venous areas were polygonal and longer with straight to undulating anticlinal walls. While paracytic stomata were randomly distributed, diallelocytic and laterocyclic stomata were also observed. Subsidiary cells were present with straight anticlinal walls. Starch grains were less abundant and occur within the epidermal 
cells and walls. Druses were also present.

\section{Venation (Plate 5)}

Areole is polygonal of various sizes and shapes,
Veins consist of tracheids. Veinlet ending could be linear or straight, curve, forked, one or two nerve endings. Starch grains abundant, scattered, crystal druses were plenty.
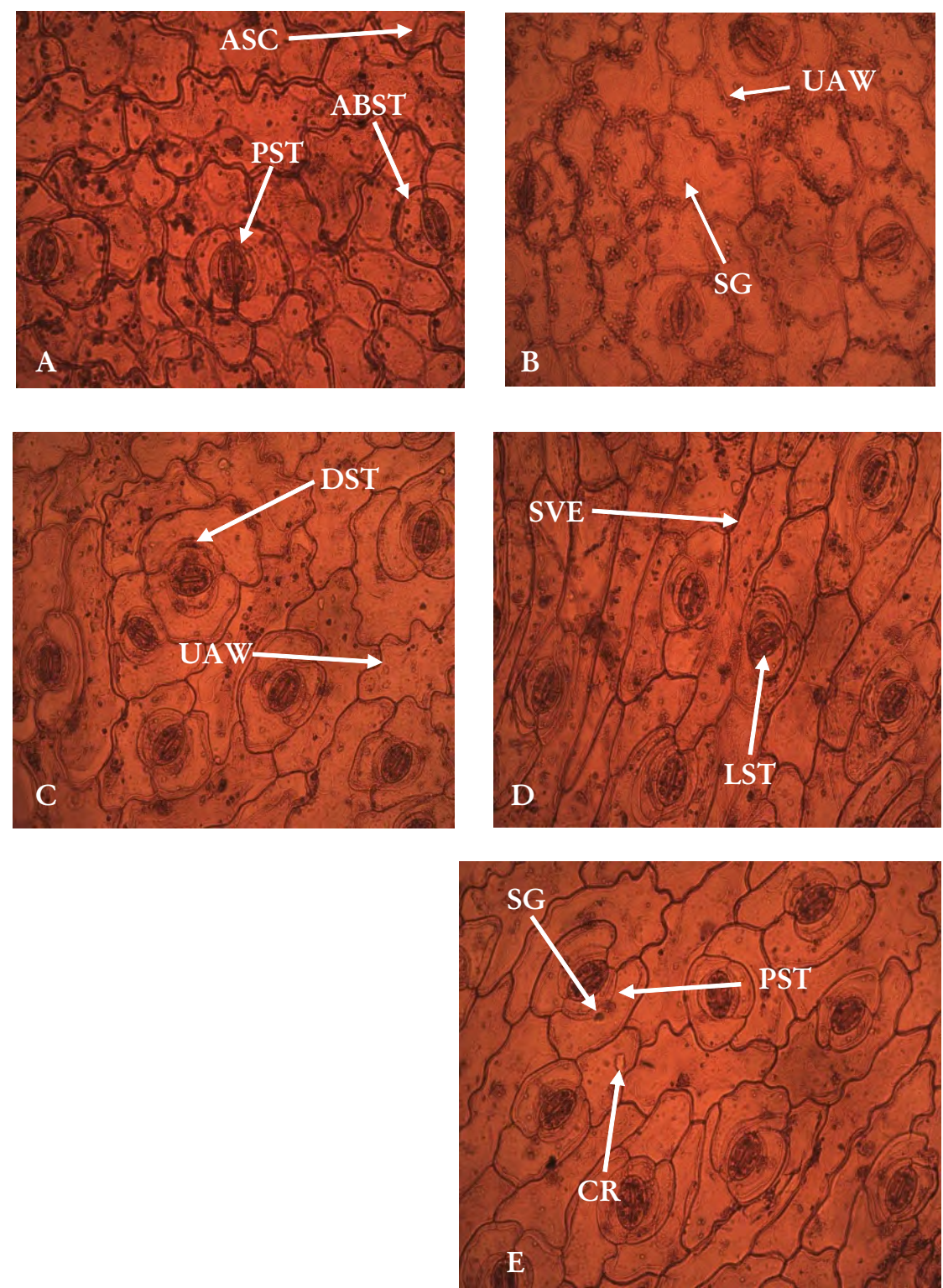

PLATE 4: Adaxial and Abaxial Surfaces of Foliar Epidermal Studies of $T$. paniculatum

A showing Asterosclereids, Paracytic stomata and abnormal stomata: B Undulating Anticlinal walls and Starch grains: CDiallelocytic stomata and Undulating Anticlinal wall: Dlaterocyclic stomata and Straight Veinous Epidermal cells: E- Crystal, Starch grains and Paracytic stomata

Abbreviations: ABST Abnormal stomata, ASC Asterosclereids, CR - Crytal, DST - Diallelocytic Stomata, LST - Laterocyclic Stomata, PST - Paracytic Stomata, SG Starch Grain, SVE - Straight Venous epidermal cells, UAW - Undulating Anticlinal walls.

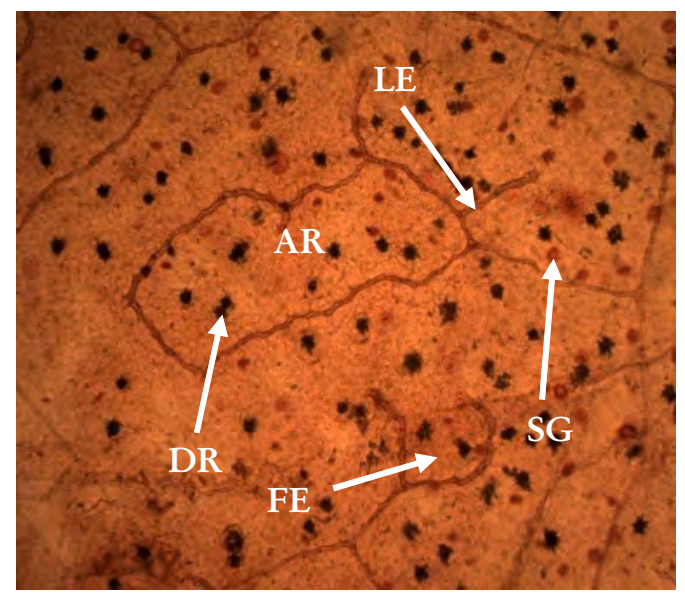

Plate 5: Venation patterns of T.paniculatum

Abbreviations: AR - Areole, DR - Druse, FE - Forked Ending, LE - Linear Ending, SG Starch Grain. 
Transverse Sections of Leaf Lamina (PLATE $6 \mathrm{~A}$ and $\mathrm{B}$ )

Stomata and osteosclereids were observed on the leaf lamina. Bundle sheath were present at regular intervals, Sclerenchyma tissue differentiates the epidermal from the mesophyll. The upper epidermis and the lower epidermis are biseriate to triseriate. The bundle sheaths demarcate the palisade and spongy mesophyll. There are cystoliths in between the bundle sheath cells. Palisade mesophyll compact rod like or elongated/cylindrical. The spongy mesophyll consists of more or less round or spherical cells with little or no air spaces. Asterosclereids were found on the lower epidermis. Cuticle is thick on the lower epidermis while the cuticle thin on the upper epidermis.

Transverse Sections of Midrib (Plate 6 C, D and E)

It is heart shaped with slight depression on median
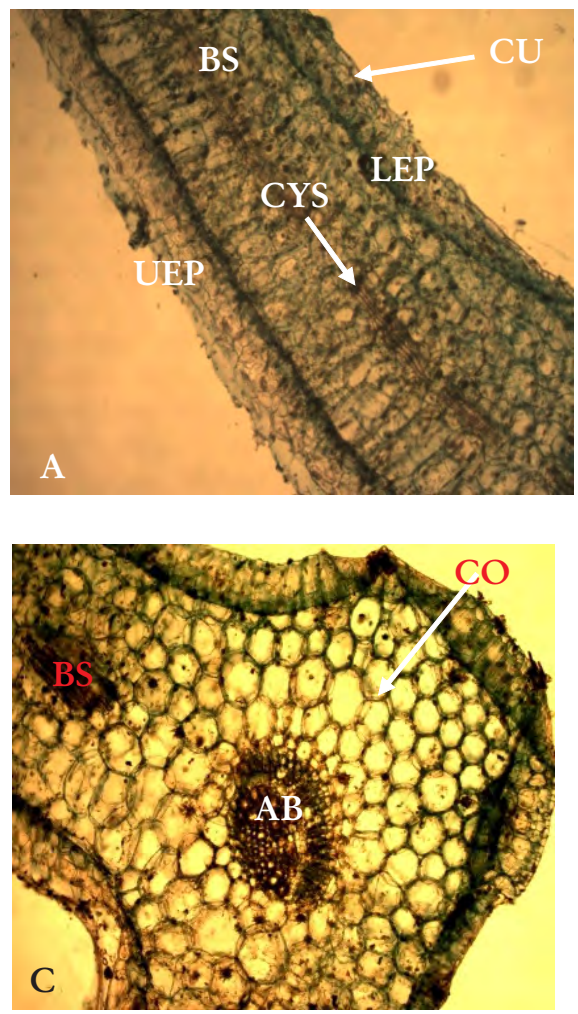

portion of upper surface. The lower epidermis is biseriate, circular to cylindrical. The upper epidermis is biseriate to triseriate with more or less circular cells. Vascular bundle is arc shaped and amphicribral. Bundle sheaths are found on the arms of midrib. Sclerenchymatous tissue lines the upper epidermis.

\section{Transverse Sections of Petiole (Plate 7)}

Heart shaped with slight depression on the median part of the adaxial surface. The cuticle was thin. The adaxial portion forms a cap on the abaxial portion. Both the abaxial and adaxial epidermis were biseriate, with cylindrical, circular and polygonal cells. Hypodermis was present and one layered. The ground tissue was collenchyma, vascular bundle was amphicribral with 3-4 medullary bundles extending on both sides of the vascular bundles. Druses were present.
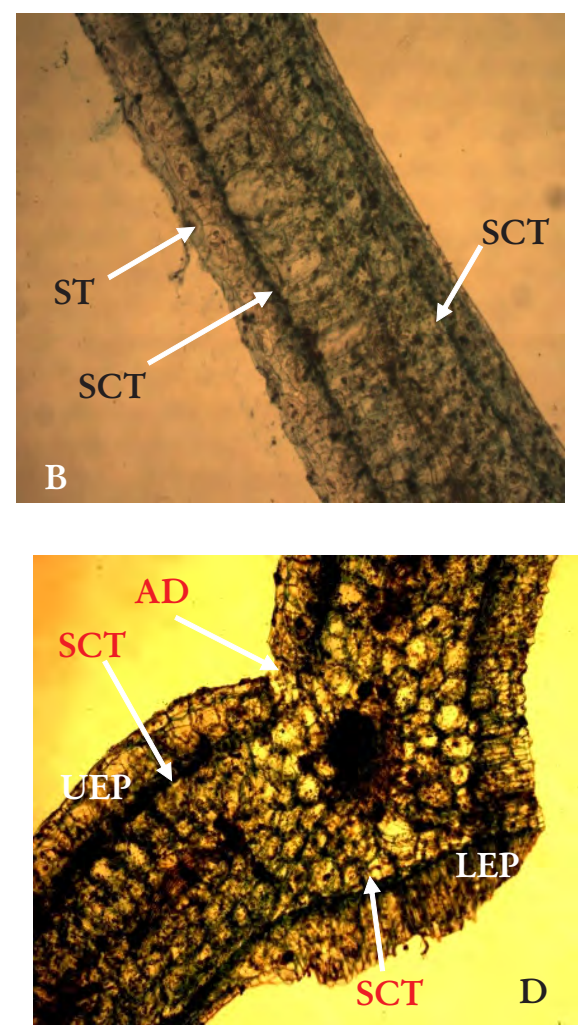


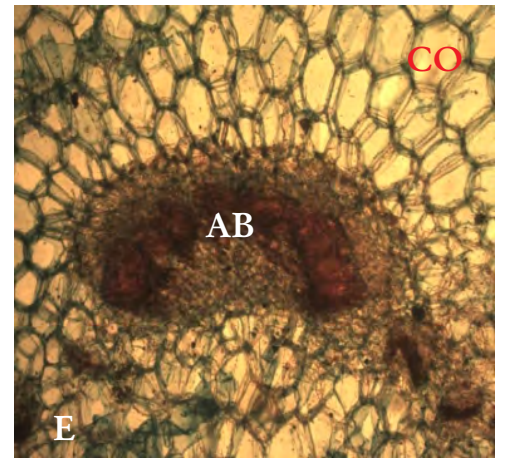

Plate 6: Transverse Section of leaf lamina and midrib of $T$. paniculatum

A-Bundle sheath, Cuticle, Cystolliths, Lower epidermis and Upper epidermis: B- Sclerenchyma tissue and Stomata: C- Amphicribral bundle, Bundle sheath and Collenchyma: D-Adaxial depression, Lower epidermis, Sclerenchyma tissue, Upper epidermis: E-Amphicribal bundle and Collenchyma

Abbreviations: $\mathrm{AB}$ - Amphicribral bundle, $\mathrm{AD}$ - Adaxial depression, BS - Bundle sheath, CO - Collenchyma, CU - Cuticle, CYS - Cystolliths, LEP - Lower Epidermis, SCT - Sclerenchyma tissue, SG - Starch grain, UEP - Upper Epidermis,

Plate 7: Transverse Section of Petiole of $T$. paniculatum

Abbreviations: $\mathrm{AB}$ - Amphicribral bundle, AD Adaxial depression, BS - Bundle sheath, CO Collenchyma, CU - Cuticle, LEP - Lower Epidermis.

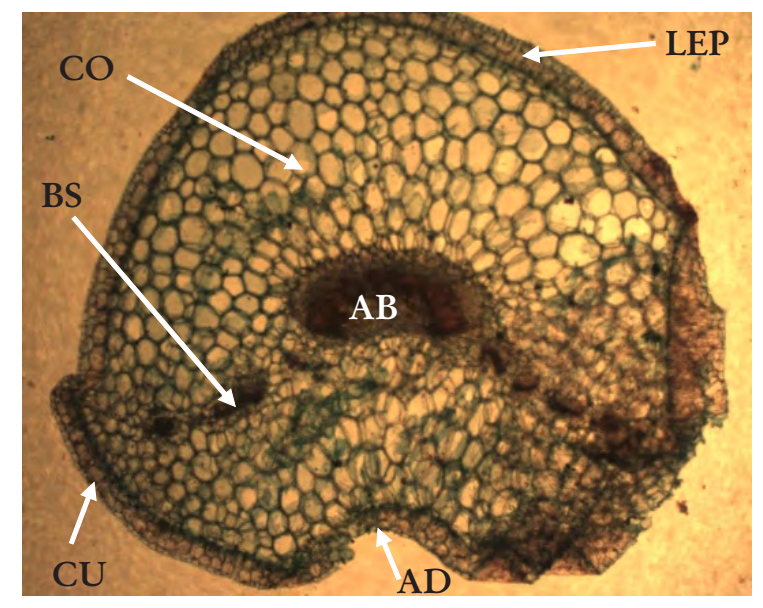

\section{DISCUSSION}

The use of anatomical features in plants to delimit members of a family, genus or between species is well documented in literature. Ogburn and Edwards (2009) reported that anatomical characters are particularly appropriate to investigate the relationship between forms, functions and adaptation at a macro-evolutionary scale. Leaf anatomical feature such as nature of epidermal cells and anticlinal walls have been used to elucidate the differences between members of a genus. Scatena et al. (2005) reported that leaf epidermal tissue characteristics have an important role in taxonomy and in determining the number of plant genera and species. Munir et al. (2011) noted that the epidermis possesses a number of important diagnostic characters that offer valuable clues for identification. These diagnostic characters include size, shape and orientation of stomata, guard cells, subsidiary cells and structural peculiarities of epidermal cell walls, length and width of the epidermal cells with distinctive or specialised trichomes.
This study showed that the epidermal cells in $T$. triangulare and T. paniculatum are irregular, polygonal with wavy to undulating anticlinal walls. This correlates with the findings of Kadiri (2006) on $T$. triangulare and $T$. cuneifolium with irregular shaped epidermal cells and curved to undulating anticlinal walls. Irregular epidermal cells with undulating anticlinal walls are generic feature. Asterosclereids were found on the adaxial surface of the two species but absent on the abaxial surface of the leaves of the two species. In T. triangulare macro sclereids were also observed on the adaxial surface of the leaves. Non glandular unicellular trichome was observed on the abaxial leaf surface of T. paniculatum. The presence of Asterosclereids on the leaves' adaxial surface is common to the two species. The leaf epidermal features may not be useful in delimiting the two species but shows generic affinity.

Stomata occur on the abaxial and adaxial surfaces in the leaves of the two species (amphistomatic). 
Stomata are paracytic accompanied by laterocyclic stomata. However Nyananyo and Olowokudejo (1986) reported that parallellocytic was observed in the Talinum species they studied. Kadiri (2006) also reported that stomata in the species of Talinum are paracytic although they may be accompanied by other stomata types. Thakur and Patil (2011) noted that the predominant stomata type may be employed for taxonomic delineation and that the occurrence of more than one type of stomata is a reflection of the precarious balance between the influences operating at a level of meristemoid which tend to cause the formation of stomata mother cells on one hand and influence operating at the level of organ involved in the orientation of cell division on the other hand.

Winkinson (1979) noted that the taxonomic significance of the similarity of the stomatal apparatus in a mature leaf often provides a reliable diagnostic character, especially when the ontogeny of the stomata is unknown or different. The presence of both paracytic stomata in the two species shows that they are related and have a common evolutionary origin and are generic characters for the genus. Another character that is of importance to the genus is the presence of abnormal stomata on abaxial and adaxial surfaces of the leaves in T. triangulare but restricted to the abaxial surface of the leaves in T. paniculatum. The abnormal guard cells are characterized by unopened stomata, a stoma with one guard cell and no guard cell. These show generic affinity between the species.

Leaf architecture especially the size and shape of the areoles and free ramifications have been useful in distinguishing between the species (Colombo et al., 2007). The use of venation pattern and areolar area in delimiting the species of the genus Ficus was reported by Ogunkunle (2013). Areoles are polygonal in T. triangulare and T. paniculatum. Veins consist of tracheids. Veinlet ending could be linear or straight, curve, forkated. Areoles are also characterized by presences of druses and starch grains.

The transverse section of the leaves of the two species of Talinum studied showed similar architecture; stomata are found on the adaxial and abaxial epidermis, presence of bundle sheath cells which lines the lamina or blade, the epidermal portions are demarcated from the mesophyll by sclerenchyma tissue and upper and lower epidermis biseriate to triseriate. The mesophyll is not differentiated in T. triangulare (mesophyll cells are more or less spherical) while it is differentiated into palisade and spongy mesophyll in T. paniculatum. Palisade cells are more or less cylindrical while the spongy cells are more or less spherical or round. The bundle sheaths demarcate the palisade mesophyll from the spongy mesophyll. Ogburn and Edwards (2009) reported of little differentiation between the palisade and spongy mesophyll in Cactaceae and its relatives but pointed out that members of the genus Talinum have greater mesophyll differentiation. Swarna and Ravindhran (2013) reported uniseriate epidermis and differentiated mesophyll in T. triangulare.

Generic features of the leaf blade that are common to the two species are presence of stomata on the adaxial and abaxial epidermis, presence of bundle sheath cells which lines the lamina or blade, the epidermal portions are demarcated from the mesophyll by sclerenchyma tissue and upper and lower epidermis biseriate to triseriate.

Both transverse section of the midrib is dorsiventrally shaped with slight depression on median portion of upper surface. The lower epidermis is biseriate, circular to cylindrical. The upper epidermis is biseriate to triseriate with more or less circular cells. Bundle sheaths are found on the arms of midrib. Sclerenchyma tissue lines the upper epidermis. Vascular bundle is arc shaped and amphicribral in T. paniculatum but collateral closed in T. triangulare. The dorsiventral nature of the midrib and presence of collateral bundle in T. triangulare was reported by Brasilero et al., (2016)

Petioles provide many useful anatomical characters and are widely used in other aspects of taxonomy and have been largely applied to the elucidation of phylogenetic relationship (Unamba et al., 2011. The distinguishing characters of taxonomic value include the variation in shapes of 
the petioles, the variation in the number, arrangement and shape of vascular bundles, type and mode of distribution of trichomes on the petioles as well as types and distribution of crystals on the petioles (Essiett, 2010).

The transverse section of the petiole is heart shaped in T. paniculatum but more or less circular in T. triangulare. Both have slight depression on the median part of the adaxial surface. The cuticle is thin. The adaxial portion forms a cap on the abaxial portion in T. paniculatum. Both the abaxial and adaxial epidermis are biseriate, with cylindrical, circular and polygonal cells in $T$. paniculatum but in $T$. triangulare, the abaxial surface is uniseriate to biseriate while the adaxial epidemis is uniseriate to multi-seriate, with cylindrical, circular and polygonal cells. Hypodermis is present and one layered in $T$. paniculatum. The ground tissue is collenchyma and vascular bundle is amphicribral in both species but $T$. paniculatum has additional 3-4 medullary bundles extending on both sides of the vascular bundles. Druses were present.

Generic features of the petiole that show close relationship between $T$. triangulare and $T$. paniculatum include slight depression on the median part of the adaxial surface, uniseriate to multiseriate epidermis, thin cuticle, presence of druses, collenchymatous ground tissues, and amphicribral vascular bundles. T. paniculatum differs from $T$. triangulare by the possession of additional 3-4 medullary bundles extending on both sides of the vascular bundles, the occurrence of the hypodermis and the formation of cap on the abaxial portion by the adaxial epidermis. Crystal druses are found in the two species; these are generic characters.

\section{CONCLUSION}

This report has filled part of the knowledge gap in the understanding of the taxonomic relationship between the two species of the genus Talinum studied. Anatomical features common to both species indicate that they belong to the same genus but there are anatomical feature that support their delimitation as different species. Theses anatomical features include the possession of additional 3-4 medullary bundles extending on both sides of the amphicribral vascular bundles, the occurrence of the hypodermis and the formation of cap on the abaxial portion by the adaxial epidermis which are exclusive to $T$. paniculatum.

\section{REFERENCES}

Andarwulan, N., Batari, R., Sandrasari, D.A., Bolling, B. and Wijaya, H. 2010. Flavonoid content and antioxidant activity of vegetables from Indonesia. Food Chemistry, 121:1231-1235.

Brasilero, B.G., Barbosa J.B., Jamal C.M., Goncalves O., Coelho L., Ronchie R. and Pizziolo V.R. (2016). Anatomical characterization, chemical composition and cytotoxity of Talinum triangulare (Jacq). Willd. (Portulacaceae). Ciencia e Natura, Santa Maria, 38(2): 665-674.

Colombo, P.V., Spadaro, V. and Raimondo, F.M. (2007). Morpho-anatomical analysis of Viola tineorum and V.ucriana (Violaceae) endemic to the mountains around Palermo (NW-Sicily). Bocconea, 21:233-247.

Essiett, U.A. (2010). Petiole anatomy for systematic purposes in Eremonastax polysperma, Justica insularis and Asystacia gangetica (Acanthaceae). World Journal of Applied Science and Technology, 2(1): 69 - 75.

Ezekwe, M. O., Besong, S. A, Igbokwe P.E. and Ezekwe E.I. 2002. Beneficial influence of purslane and waterleaf supplementation on cardiovascular disease risk in humans. FASEB Journal, 16(4): A639.

Fontem, D. A and Schippers, R.R. 2010. Talinum triangulare (Jacq.) Willd, Record from protabase: Grubben G.J.H., Denton O.A. (Editors), PROTA (Plant Resources of Tropical Africa/Ressources ve'ge'tales de l'Afrique tropicale), Wageningen, Netherlands,

Hutchinson, J. and Dalziel, J.M. 1954. Flora of West Tropical Africa. Second Edition, Volume I Part I. White Friars Press, London.

Kadiri, A.B. (2006). Comparative foliar micromorphological characters of the species 
of Portulacaceae in Nigeria. Bulletin of Pure and Applied Sciences - Botany, 25, (1): 21-29.

Kumari, K.D., Hasanthi K.B. and Gamage R.N.N. (2017). A comparative study on In Vitro antibacterial Activity of different leaf extracts of Medicinal plant Talinum paniculatum. International Journal of Pharmacy \& Pharmacentical Research (Human) 10(3): 143-154.

McNeil, J. (1974). Synopsis of a revised classification of Portulacaceae. Taxon 23: $725-728$.

Mbang A., Owolabi S., Jaja O. and Opeyemi J.O. 2008. Evaluation of the antioxidant activity and lipid peroxidation of the leaves of Vernonia amygdalina. Journal of Complementary Integrated Medicines 5. doi:10.2202/1553-3840.1152.

Molero J., Davina J.R., Honfi A.L. Franco D. and Rovira A. 2006. Chromosome studies on plants from Paraguay II. Candollea 61: $373-392$

Mosango M. Talinum paniculatum (Jacq.) Gaertn. .Accessed August 27, 2017

Munir, M., Khan M.A., Ahmed M., Beno A., Ahmed S.N., Tariq K., Tabassur S., Mukhtar T., Ambreen M. and Bashir S. (2011). Foliar Epidermal Anatomy of some Ethnobotanical Important Species of Wild Edible Fruits of North Pakistan. Journal of Medicinal plants Research, 5(24): $5871-5880$.

Nya, E.J. and Eka M.J. (2015) Morphological Characterization and Hybridization of Talinum triangulare Land Races for Desirable Metric Characters in South Eastern Nigeria. The International Journal of Science E Technoledge, 3 (7): 192-197

Nyananyo, B.L. and Olowokudejo, J.D. (1986). Taxonomic studies in the Genus Talinum Portulacaceae in Nigeria. Willdenowia, 15, 455-463.

Ogburn, R.M and Edwards E.J. (2009). Anatomical variation in Cactaceae and relatives: Traits liability and evolutionary innovation. American Journal of Botany, 96(2):391-408.
Ogunkunle, A.T.J. (2013). The Value of Leaf Epidermal Characters in Diagnosing Some Nigerian Species of Ficus L. (Moraceae). Research Journal of Botany, 8: 1-14.

Oziegbe, M. Faluyi, J.O and Idowu, J.A. (2012) Inheritance of pigmentation patterns in Talinum triangulare (Jacq.)Willd. Ife Journal of Science, 14 (2): 363-367.

Ramos M.P.O., Silva G.D.F., Duarte L.P., Peres V., Miranda R.R.S., de Souza G.H.B., Belinelo V.J. and Vieira F. 2010. Antinociceptive and edematogenic activity and chemical constituents of Talinum paniculatum Wild. Journal of Chemical and Pharmaceutical Research, 2(6):265-274.

Reis L.F.D., Cerdeira C.D., Paula B.F., Silva J.J.D., Coelho L.F., Silva M.A., Marques V.B., Chavasco J.K. and Da-Silva G. 2015. Chemical characterization and evaluation of antibacterial, antifungal, antimycobacterial and cytotoxic activities of Talinum paniculatum. Revista do Instituto de Medicina Tropical de São Paulo, 57(5): 97-405

Sidney, A.V.F., Ramosa P.O., de Fátima Silvaa G.D., Duartea L.P., Peresb V., Mirandaa R.R.S., de Souzac G.H.B. and Belinelod V.J. (2010). Antinociceptive and edematogenic activity and chemical constituents of Talinum paniculatum Willd. Journal of Chemical and Pharmaceutical Research, 2(6):265-274.

Scatena, V.L., Giuletti A.M., Borba E.L. and Van der Berge C. (2005). Anatomy of the Brazilian Ericaulaceae in correlation with taxonomy and habitat using multivariate analysis. Plant Systematics and Evolutions, 253:1-22.

Sridhar R. and Lakshminarayana G. 1993. Lipid Classes, Fatty Acids and Tocopherols of Leaves of Six Edible Plant Species. Journal of Agricultural Food Chemistry, 41:61-63.

Swarna, J. and Ravindhran R. (2013). Pharmacognostical and phytochemical evaluation of Talinum triangulare (Jacq.) Willd. International Journal of Pharmacy and Pharmaceutical Sciences, 5(2): 249256 
Thakur, H.A and Patil D.A, 2011. The Foliar epidermal studies in some hitherto unstudied Euphorbiaceae. Current Biology, 2(4): 22-30.

Thanamool, C., Papirom P., Chanlum S. and Kopittayanant S. (2013). Talinum paniculatum (Jacq.) Gaertn.: A medicinal plant with potential estrogenic activity in ovariectomized rat. International Journal of Pharmacy and Pharmaceutical Sciences, 5(2): 478-485

Unamba, C.I.N., Magwu, F.N., Daru C.M., Inyama, C.N. and Osuoha, V.U.N. (2011). Comparative petiole anatomical features and their significance in the taxonomy of five species of the genus Senna (Leguminosae). Global Research Journal of Science, 93-97. http://www. academicpublication.org/grjs.

Veselova T.D., Khalima Kh. D., Margarita V.R and Alexander C.T. 2012. Embyology of Talinum paniculatum (Jacq.) Gaertn. and Talinum triangulare (Jacq.) Willd. (Portulacaceae s.l. Caryophyllales). Wulfenia 19: 107-129

Winkinson, H.P, (1979). The Plant surface (mainly leaf). In Metcalfe, C.R and Chalk, L. (Eds). Anatomy of the Dicotyledons, $2^{\text {nd }}$ Edition, Oxford Clarendon, Press. 40-53 